\title{
Postpartum uterine involution in sheep: histoarchitecture and changes in endometrial gene expression
}

\author{
C. A. Gray ${ }^{1}$, M. D. Stewart ${ }^{1}$, G. A. Johnson ${ }^{2}$ and T. E. Spencer ${ }^{1 *}$ \\ ${ }^{1}$ Centre for Animal Biotechnology and Genomics and Department of Animal Science; and \\ ${ }^{2}$ Department of Veterinary Anatomy and Public Health, Texas A\&M University, \\ College Station, TX 77843-2471, USA
}

\begin{abstract}
After parturition, the uterus undergoes marked remodelling during involution; however, little is known of the hormonal, cellular and molecular mechanisms that regulate this process. The working hypothesis used in this study is that return of the ovine uterus to a non-pregnant state involves termination of a hormonal servomechanism that regulates endometrial gland morphogenesis and function during pregnancy. Suffolk ewes were ovariohysterectomized on postpartum days $1,7,14$ or 28 . Serum concentrations of oestradiol were high at parturition, declined to postpartum day 4 , peaked on postpartum day 6 , and then declined and remained low thereafter. Progesterone was undetectable in plasma from ewes post partum. Uterine wet mass and horn length decreased after postpartum day 1 , but ovarian mass did not change. Residual placental cotyledons were present in the maternal caruncles on postpartum days 1 and 7 and were extruded by postpartum day 14 as plaques that were resorbed by postpartum day 28. The width of the total endometrium, stratum compactum, stratum spongiosum and myometrium, as well as endometrial gland density, decreased after parturition. Most apoptotic cells in the involuting uterus were large, vacuolated and located between the endometrial glandular epithelial cells on postpartum days 1 and 7 . Immuno-
\end{abstract}

fluorescence analyses identified both $T$ and $B$ cells within the glandular epithelium on postpartum day 1 . Cell proliferation was detected in the luminal epithelium and glandular epithelium on postpartum days 1 and 7. On postpartum day 1, expression of oestrogen receptor alpha (ER $\alpha)$ was not detected in luminal epithelium and was low in glandular epithelium, but ER $\alpha$ was present in epithelia thereafter. Progesterone receptor (PR) protein was not detected in endometrial epithelia on postpartum day 1 , but was detected in the glandular epithelium thereafter. Between postpartum days 1 and 7, ER $\alpha$ and PR protein increased substantially in the endometrial glandular epithelium. On postpartum days 1-28, abundant expression of oxytocin receptor mRNA was detected in endometrial luminal epithelium and superficial to the middle glandular epithelium. Prolactin receptor (PRLR) $m$ RNA was detected in glandular epithelium on all postpartum days, whereas mRNA for uterine milk protein (UTMP), an index of secretory capacity of glandular epithelium, was present only on postpartum day 1. Collectively, these results indicate that uterine involution in ewes involves remodelling of both caruncular and intercaruncular areas of the uterine wall and termination of differentiated uterine gland functions characteristic of pregnancy.

\section{Introduction}

After parturition, the uterus undergoes involution, a process defined as the retrograde changes in female reproductive organs that return the uterus to a cyclic or non-pregnant size (for review, see Kiracofe, 1980). Uterine involution in cattle is complete when the uterine horns return to the position, size and tone of a nonpregnant or cyclic animal (Casida et al., 1968). A variety of factors, such as parity (Rasbeck, 1950; Marion and Gier, 1968), lactational status (Wiltbank and Cook, 1958; Casida et al., 1968; Riesen, 1968), nutrition (Wiltbank

*Correspondence: 442 Kleberg Center, 2471 TAMU, Texas A\&M University, College Station, TX 77843-2471, USA

Email: tspencer@tamu.edu et al., 1962; Dunn et al., 1969), breed and season, influence the time to complete uterine involution. The process of uterine involution in cattle and sheep involves an overall size reduction, loss of cotyledonary tissue, and tissue repair (Gier and Marion, 1968; van Wyk et al., 1972a,b; O'Shea and Wright, 1984). During the first week after parturition, the placentomal vasculature responsible for haematotrophic nutrition of the fetus degenerates. As a result, the uterine lumen is filled with lochia, a thick brown substance produced by autolysis of red blood cells (van Wyk et al., 1972a). This period is also characterized by dissolution of the fetal and maternal layers of the placentome and expulsion of the remaining fetal cotyledonary placenta. During the second week post partum, brown necrotic plaques are released from the involuting caruncles and fill the uterine lumen 
(van Wyk et al., 1972a). Re-epitheliazation of the caruncles occurs during the third and fourth weeks post partum (O'Shea and Wright, 1984) concurrent with decreases in uterine size, mass and horn length (van Wyk et al., 1972b). However, the histoarchitectural changes in the intercaruncular endometrium after parturition have not been reported.

During gestation, endometrial gland morphogenesis and differentiation occurs in the intercaruncular endometrium to provide increasing amounts of secreted histotroph (Stewart et al., 2000). These secretions are absorbed by areolae within the interplacentomal placenta for nutrition of the fetus (Amoroso, 1952). During pregnancy, uterine glands undergo hyperplasia between day 15 and day 50, followed by hypertrophy that precedes maximal secretion of histotroph (Wimsatt, 1950; Moffatt et al., 1987; Stewart et al., 2000). Endometrial gland morphogenesis and differentiated secretory function during gestation appear to be regulated by a hormonal servomechanism involving the sequential effects of oestrogen, progesterone, ovine placental lactogen $(\mathrm{PL})$ and ovine placental growth hormone (GH) (Spencer et al., 1999; Gray et al., 2001; Spencer and Bazer, 2002). During oestrus and metoestrus, oestrogen acts via oestrogen receptor alpha $(E R \alpha)$ to increase expression of progesterone receptor $(\mathrm{PR})$ in the endometrial epithelia (Spencer and Bazer, 1995; Spencer et al., 1996, 1999). However, continual exposure of the endometrium to progesterone downregulates PR expression in the luminal epithelium by day 13 and in the glandular epithelium by day 15 (Spencer and Bazer, 1995; Spencer et al., 1999). The absence of PR allows for oestrogen to increase $E R \alpha$ and then oxytocin receptor (OTR) gene expression in the luminal epithelium and superficial glandular epithelium (Spencer et al., 1996). After establishment of pregnancy, expression of $E R \alpha$ and PR genes are notably absent in the endometrial epithelia (Spencer and Bazer, 1995; T. E. Spencer, unpublished). The effects of progesterone to induce expression of secretory proteins, such as uterine milk proteins (UTMP) and osteopontin, in the endometrial glands are due to the negative autoregulatory effects of progesterone on epithelial PR expression (Spencer et al., 1999; Johnson et al., 2000; Spencer and Bazer, 2002). The UTMPs are members of the serpin family of serine proteinase inhibitors (Ing and Roberts, 1989) and are excellent markers of endometrial gland differentiated function, because they are the most abundant secreted proteins in the ovine uterus (Bazer et al., 1979; Moffat et al., 1987; Stewart et al., 2000). Intrauterine infusion of ovine placental lactogen into the uterus of ewes treated with progesterone and interferon tau $(\mathrm{IFN}-\tau)$ increases endometrial gland proliferation and production of UTMP (Spencer et al., 1999). The effects of placental lactogen on endometrial glandular epithelium are predominantly mediated by homodimerization of the prolactin receptor (PRLR). The PRLR is expressed exclusively in the endometrial glandular epithelium during pregnancy (Stewart et al., 2000).

The working hypothesis used in this study is that uterine involution involves termination of the hormonal servomechanism regulating uterine gland morphogenesis and secretory function. Therefore, processes involved in return of the uterine glands to a non-pregnant state may involve alterations in cell type specific expression of hormone receptors as well as cell death and proliferation. Consequently, this study determined the effects of postpartum day on: (1) circulating concentrations of oestradiol and progesterone; (2) ovarian and uterine histoarchitecture; and (3) spatial alterations in endometrial cell proliferation, apoptosis and expression of $E R \alpha, P R, O T R, P R L R$ and UTMP in the intercaruncular endometrium.

\section{Materials and Methods}

\section{Animals}

Experimental and surgical procedures were in compliance with the Guide for Care and Use of Agriculture Animals and were approved by the Institutional Agricultural Animal Care and Use Committee of Texas A\&M University. Multiparous Suffolk ewes $(n=17), 5-8$ years of age, were mated with rams of proven fertility, and pregnancy was determined by transabdominal ultrasonography. Ewes were pastured during most of gestation and fed alfalfa hay ad libitum and supplemented with whole corn during the last month of gestation. Ewes were checked twice a day for signs of labour or parturition. The number of lambs born to each ewe was recorded at parturition. Lambs were observed twice a day to ensure that they were nursing ewes.

\section{Experimental design and tissue collection}

Blood samples were collected from ewes bled daily via jugular venepuncture with Vacutainer evacuated blood collection tubes with sodium heparin (for plasma) or no additive (for serum) (Becton-Dickinson, Franklin Lakes, NJ) beginning at parturition (day of birth or postpartum day 0) to ovariohysterectomy. Plasma or serum was isolated from blood samples by centrifugation at $1500 \mathrm{~g}$ for $10 \mathrm{~min}$ and stored at $-20^{\circ} \mathrm{C}$.

Ewes were assigned randomly to undergo ovariohysterectomy on postpartum day $1,7,14$ or $28(n=4$ 5 ewes per day). At surgery, ovarian mass, uterine mass and uterine horn length were measured. Ovaries were fixed in freshly prepared $4 \%$ paraformaldehyde in PBS ( $\mathrm{pH}$ 7.2). Residual placentomal or caruncular and intercaruncular areas of the uterine wall were dissected from the uteri of ewes on postpartum days 1,7 or 14 , and sections (of about $1 \mathrm{~cm}$ ) fixed in $4 \%$ paraformaldehyde. On postpartum day 28, sections from the mid-portion of each uterine horn were fixed in 
$4 \%$ paraformaldehyde. After $24 \mathrm{~h}$, fixed tissues were dehydrated through a graded series of ethanol solutions and embedded in Paraplast Plus (Oxford Labware, St Louis, MO) for histological analyses. Several sections of the uterine horns were also embedded in optimal cutting temperature (OCT) compound (Miles, Oneota, $\mathrm{NY}$ ), snap-frozen in liquid nitrogen, and stored at $-80^{\circ} \mathrm{C}$.

\section{Steroid radioimmunoassay}

Progesterone concentrations in plasma samples were determined in a single assay using an active progesterone radioimmunoassay kit (Diagnostic Systems Laboratories, Inc., Webster, TX) as described by Gray et al. (2000a). Assay sensitivity was $0.1 \mathrm{ng}$ progesterone $\mathrm{ml}^{-1}$, and the intra-assay coefficient of variation was $5.2 \%$. Serum samples were extracted with ethyl ether. Oestradiol concentrations in serum extracts were determined using an active oestrogen radioimmunoassay kit (Diagnostic Systems Laboratories, Inc.) according to the manufacturer's recommendations. Assay sensitivity was $1 \mathrm{pg}$ oestradiol $\mathrm{ml}^{-1}$, and the intra-assay coefficient of variation was $10 \%$. For both steroid assays, results were calculated using the AssayZap program (Biosoft, Ferguson, $\mathrm{MO})$.

\section{Histology and morphometry}

Sections $(5 \mu \mathrm{m})$ of paraffin wax-embedded tissues were stained with haematoxylin and eosin or Masson's trichrome stain as described by Gray et al. (2002). For morphometry, sections $(n=5)$ of the uterus from each ewe were stained with haematoxylin and eosin, photomicrographed, and images were analysed using Scion Image software (Scion Corporation, Frederick, $\mathrm{MD})$. Measurements were standardized using the image of a stage micrometer at the same magnification. In the intercaruncular endometrium, total endometrial depth, width of stratum compactum and stratum spongiosum, gland cross-section width, total myometrial depth, and width of inner circular and outer longitudinal layers were measured using computer-assisted image analysis software. Morphometrical width determinations were made from multiple measurements $(n=5-9)$ of each uterine section.

\section{Immunohistochemistry}

Immunoreactive proliferating cell nuclear antigen (PCNA), ER $\alpha$ and PR proteins were localized in uterine tissue sections $(5 \mu \mathrm{m})$ using specific antibodies and a super $\mathrm{ABC}$ mouse/rat IgG kit (Biomeda, Foster City, CA) as described by Gray et al. (2000a,b). Mouse antibody to PCNA was purchased from DAKO Corporation (Carpinteria, CA). Rat antibody to human $\mathrm{ER} \alpha(\mathrm{H} 222)$ was provided by G. Greene (Abbott Laboratories, Chicago, IL). Mouse monoclonal antibody to the human PR
(MA1-411) was purchased from Affinity Bioreagents (Golden, CO). PCNA antibody was used at a final concentration of $1 \mu \mathrm{g} \mathrm{ml}^{-1}$, and ER $\alpha$ and PR antibodies were both used at a final concentration of $5 \mu \mathrm{g} \mathrm{ml}^{-1}$. Negative controls included substitution of the primary antibody with purified mouse IgG (PCNA and PR) or rat $\lg \mathrm{g}(\mathrm{ER} \alpha)$.

\section{Immunofluorescence analyses}

Mouse monoclonal antibodies used for immunocytochemical identification of interepithelial immune cells were provided by W. Davis (Washington State University) and included CACT + 80C specific for CD8, GC1A specific for CD4, GS5A specific for B cells and naïve $T$ cells, BAQ44A specific for BAQ44adefined molecule expressed on B cells, DH59B specific for CD172a expressed on monocytes-macrophages, dendritic cells and macrophages, and BA7A1 and BAQ44A specific for the $\gamma \delta$ T-cell surface markers WC1-N1 and WC1-N2, respectively. Proteins were localized in frozen uterine tissue sections $(8-10 \mu \mathrm{m})$ by immunofluorescence staining as described by Johnson et al. (1999). Frozen sections were fixed in methanol at $-20^{\circ} \mathrm{C}$, permeabilized with $0.3 \%$ Tween 20 in $0.02 \mathrm{~mol}$ $\mathrm{PBSI}^{-1}$, blocked in $10 \%$ normal goat serum, and incubated overnight at $4{ }^{\circ} \mathrm{C}$ with $12 \mu \mathrm{g}$ primary antibody $\mathrm{ml}^{-1}$. Immunoreactive protein was then detected using a fluorescein-conjugated goat anti-mouse IgG (Zymed, San Fransisco, CA). Coverslips were placed over a layer of Prolong antifade mounting reagent (Molecular Probes, Eugene, OR).

\section{In situ apoptosis staining}

Paraffin wax-embedded sections of uterine wall $(5 \mu \mathrm{m}$ in thickness) from postpartum ewes were evaluated using the TACS 2 TdT in situ apoptosis kit from Trevigen (Gaithersberg, MD) following the manufacturer's directions. Positive controls were tissues that were digested with nuclease to expose DNA ends. Labelling was visualized using diaminobenzidine as a chromogen, and sections were counterstained with methyl green.

\section{In situ hybridization}

The OTR, PRLR and UTMP mRNAs were localized in uterine tissue sections by in situ hybridization as described by Spencer et al. (1999), Gray et al. (2000a) and Stewart et al. (2000). Uterine sections $(5 \mu \mathrm{m})$ were deparaffinized, rehydrated, deproteinated and hybridized with radiolabelled antisense or sense ovine OTR (Riley et al., 1996), bovine PRLR (Scott et al., 1992) or ovine UTMP (Stewart et al., 2000) cRNAs generated from linearized plasmid templates using in vitro transcription with $\left[\alpha-{ }^{35}\right.$ S]UTP. Autoradiographs of slides were prepared using Kodak NTB-2 liquid 
photographic emulsion. Slides were stored at $4{ }^{\circ} \mathrm{C}$ for 1-2 weeks, developed in Kodak D-19 developer, counterstained with Harris' modified haematoxylin (Fisher Scientific, Fairlawn, NJ), dehydrated through a graded series of alcohols to xylene, and coverslips were applied.

\section{Photomicroscopy}

Photomicrographs were taken using a Nikon Eclipse E1000 photomicroscope (Nikon Instruments, Inc., Melville, NY). Digital images were captured using a Nikon DXM 1200 digital camera and assembled using Adobe Photoshop 5.5 (Adobe Systems, Seattle, WA). For immunofluorescence analyses, representative fluorescence images of cross-sections exhibiting immunological crossreactivity were recorded using a Ziess Axioplan microscope (Carl Zeiss, Thornwood, NY) equipped with a Hamamatsu chilled 3CCD colour camera (Hamamatsu, Japan) using Photoshop 5.0 (Adobe Systems) image capture software.

\section{Statistical analyses}

Data were subjected to least-squares ANOVA using the general linear models procedure of the statistical analysis system (SAS, 2000). For uterine mass and length measurements, the number of suckling lambs was used as a covariate in statistical models. All values were logtransformed to alleviate heterogeneity of error variance. Statistical models for analysis of morphometry data included main effects of postpartum day, ewe within postpartum day, tissue section, and microscopic field within tissue section, and the appropriate interactions. Initial analyses indicated that uterine wall location, tissue section and microscopic field within section were not significant sources of variation. Data are presented as least-square means (LSM) with pooled standard errors (SE).

\section{Results}

\section{Circulating concentrations of progesterone and oestradiol}

Concentrations of circulating oestradiol in serum changed with postpartum day $(P<0.08$, fifth order effect of day). Serum concentrations of oestradiol were high at parturition, declined to postpartum day 4, peaked on postpartum day 6 ( $65 \mathrm{pg}$ oestradiol $\left.\mathrm{ml}^{-1}\right)$, and then declined to an average of $8 \mathrm{pg}$ oestradiol $\mathrm{ml}^{-1}$ thereafter (data not shown). Plasma concentrations of progesterone were below detectable limits of the assay and not affected $(P=0.65)$ by postpartum day (data not shown).

\section{Gross observations and measurements}

Each postpartum ewe maintained one or two suckling lambs. The ovaries of all ewes contained antral follicles at various stages of development and one or more corpora lutea (data not shown). Ovarian mass was not affected $(P=0.262)$ by postpartum day (data not shown).

As expected, uterine mass $(P<0.01$, quadratic) and uterine horn length $(P<0.01$, quadratic) decreased between postpartum days 1 and 28 (Table 1). Gross anatomical changes in the involuting ovine uterus are illustrated (Fig. 1). A thick, dark lochia was present in the uterine lumen on postpartum days 1, 7 and 14, but was completely absent on postpartum day 28 . On postpartum days 1 and 7 , the residual placentomes or caruncles were distended and contained dark brown plaques, which were probably a combination of residual placental cotyledonary tissue and haemolysed blood. By postpartum day 14, these plaques were no longer attached to the uterus, but were free within the uterine lumen. By postpartum day 28, no plaques remained in the uterine lumen.

\section{Histoarchitecture and morphometry}

The histoarchitectural changes in the uterine wall are shown (Fig. 2), and morphometrical analyses of the intercaruncular endometrium are summarized (Table 1). In the intercaruncular areas of the uterus (Fig. 2), the width of the endometrium and myometrium was maximal on postpartum day 1 . The endometrium contained enlarged endometrial glands and expanded stroma with little discernable extracellular matrix (ECM). Large, vacuous, nucleated cells were present within or between the endometrial glandular epithelium cells. The entire intercaruncular area contained many folds. On postpartum day 7 , the endometrium was less folded with a noticeably ruffled luminal epithelium. Endometrial width was lower with an apparent reduction in extracellular space between cells in the stroma and distance between endometrial glands. A marked increase in extracellular matrix (ECM) staining was observed in the stroma. On postpartum day 14, the width of the endometrium and myometrium reached a minimum. Uterine glands appeared more organized and smaller than on postpartum day 7 . The intercaruncular endometrium contained less folding, and the luminal epithelium was less ruffled in appearance. By postpartum day 28 , the endometrium was histoarchitecturally similar to that of non-pregnant ewes. The luminal epithelium was noticeably less ruffled and less columnar. Although endometrial gland diameter reached a minimum on postpartum day 14 , total endometrial and myometrial width increased slightly from postpartum day 14 to postpartum day 28.

On postpartum days 1 and 7 , the residual placentomes or caruncles contained a combination of residual 
Table 1. Gross measurements of the uterus and morphometric measurements of the endometrium and myometrium in the intercaruncular areas of the ovine uterus on postpartum days $1,7,14$ and 28

\begin{tabular}{|c|c|c|c|c|c|c|c|c|c|}
\hline \multirow[b]{2}{*}{$\begin{array}{l}\text { Postpartum } \\
\text { day }\end{array}$} & \multirow[b]{2}{*}{$\begin{array}{l}\text { Uterine } \\
\text { wet mass } \\
(\mathrm{g})\end{array}$} & \multirow[b]{2}{*}{$\begin{array}{l}\text { Uterine } \\
\text { horn length } \\
(\mathrm{cm})\end{array}$} & \multirow[b]{2}{*}{$\begin{array}{l}\text { Endometrium } \\
\qquad(\mu \mathrm{m})\end{array}$} & \multicolumn{3}{|c|}{ Intercaruncular endometrium } & \multirow[b]{2}{*}{$\begin{array}{l}\text { Myometrium } \\
(\mu \mathrm{m})\end{array}$} & \multicolumn{2}{|c|}{ Myometrium } \\
\hline & & & & $\begin{array}{c}\text { Stratum } \\
\text { compactum } \\
(\mu \mathrm{m})\end{array}$ & $\begin{array}{c}\text { Stratum } \\
\text { spongiosum } \\
(\mu \mathrm{m})\end{array}$ & $\begin{array}{c}\text { Gland } \\
\text { diameter } \\
(\mu \mathrm{m})\end{array}$ & & $\begin{array}{l}\text { Inner } \\
\text { circular } \\
(\mu \mathrm{m})\end{array}$ & $\begin{array}{c}\text { Outer } \\
\text { longitudinal } \\
(\mu \mathrm{m})\end{array}$ \\
\hline 1 & 1159 & 43 & 2585 & 161.4 & 2415 & 100.3 & 4355 & 2661 & 1903 \\
\hline 7 & 423 & 40 & 2056 & 293.6 & 1832 & 109.7 & 3964 & 2018 & 1972 \\
\hline 14 & 203 & 29 & 903 & 155.6 & 680 & 47.6 & 2002 & 1044 & 1043 \\
\hline 28 & 153 & 18 & 1174 & 197.0 & 914 & 37.8 & 2679 & 1199 & 1380 \\
\hline SE & 34 & 1 & 50 & 7.2 & 60 & 6.6 & 73 & 50 & 37 \\
\hline$P$ value & 0.0001 & 0.0001 & 0.0001 & 0.0001 & 0.0001 & 0.001 & 0.0001 & 0.0001 & 0.0001 \\
\hline
\end{tabular}

Data are presented as least-square means with overall pooled standard errors generated by ANOVA.
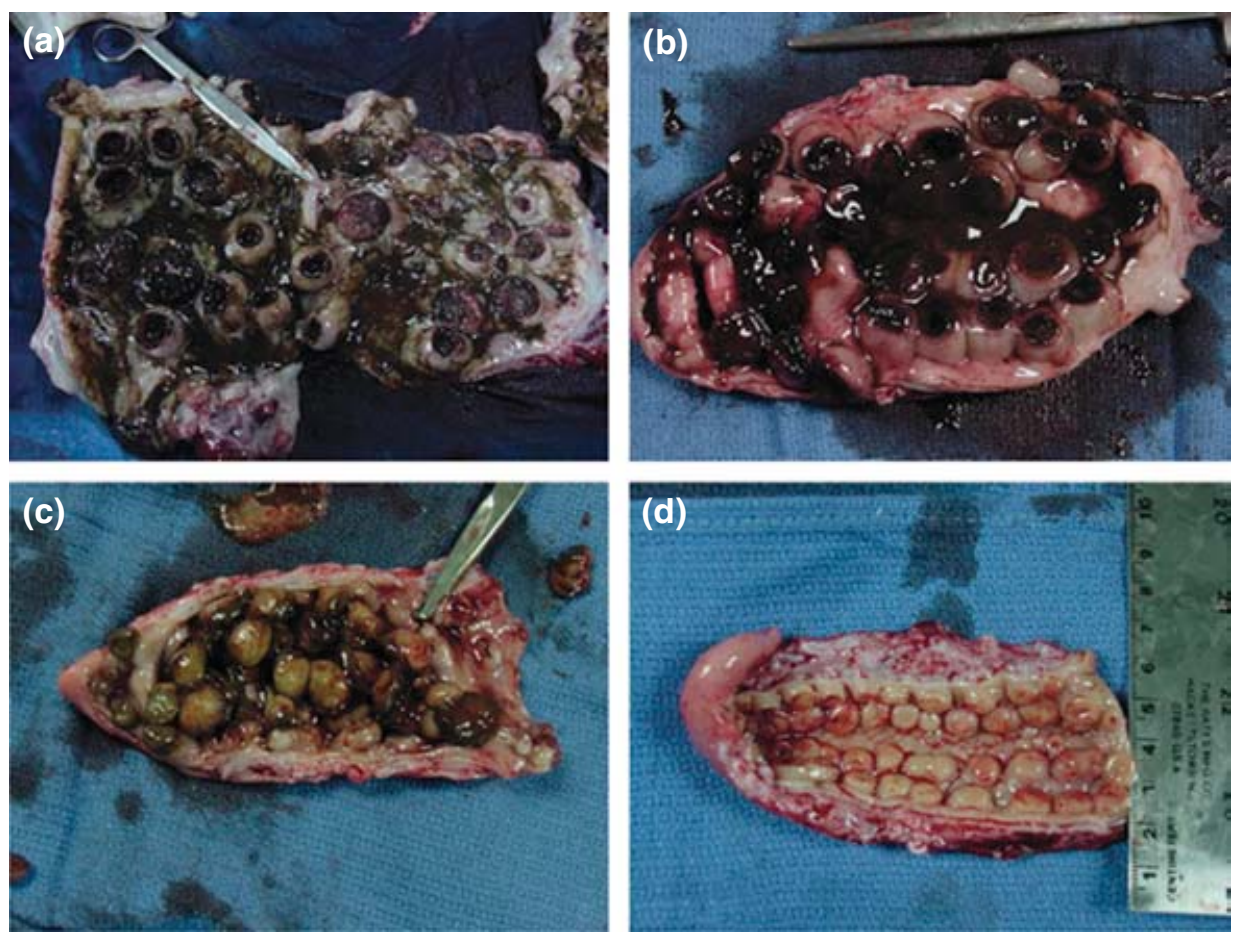

Fig. 1. Gross structure of the ovine reproductive tract during the postpartum period. Photographs of uteri collected on (a) postpartum day 1, (b) postpartum day 7, (c) postpartum day 14 and (d) postpartum day 28. Note the changes in shape and conformation of placentomes, as well as the presence of dark fluid (lochia) in the uterine lumen on postpartum days 1 and 7; also note the presence of plaques in the uterine lumen on postpartum day 14.

placental cotyledonary tissue and blood clots (Fig. 2). Numerous blood vessels were observed in the remaining placental cotyledonary tissue on postpartum days 1 and 7. By postpartum day 14, placental cotyledonary tissue was absent from the caruncles. Before postpartum day 28 , luminal epithelium was not observed on the residual placentomes or caruncles. On postpartum day 28 , the caruncles were everted and contained luminal epithelium covering most, but not all, of the luminal surface.

\section{Cell proliferation and apoptosis}

Immunoreactive PCNA protein was used as a marker for cell proliferation (Fig. 3). PCNA is a highly conserved accessory protein of DNA polymerase $\delta$, synthesized during the late $\mathrm{G} 1$ and $\mathrm{S}$ phases of the cell cycle, essential for DNA synthesis, and correlated with cellular proliferation (Waseem and Lane, 1990). On postpartum days 1 and 7, PCNA protein was most abundant in luminal epithelium and glandular epithelium. In uteri of 

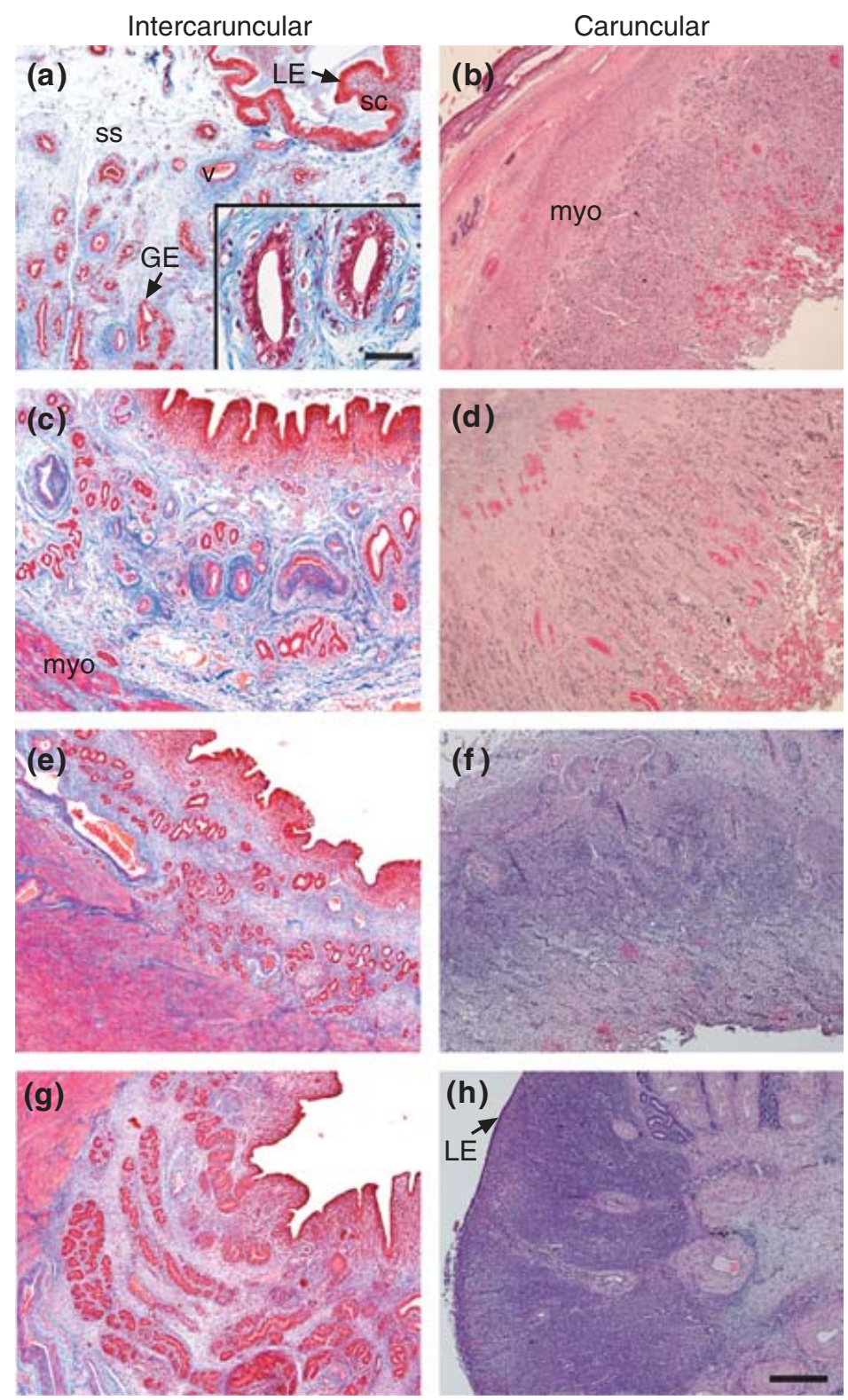

Fig. 2. Histology of the intercaruncular and caruncular areas of the uterine wall on $(\mathrm{a}, \mathrm{b})$ postpartum day $1,(\mathrm{c}, \mathrm{d})$ postpartum day $7,(\mathrm{e}, \mathrm{f})$ postpartum day 14 and $(g, h)$ postpartum day 28. Intercaruncular area: sections were stained with Masson's Trichrome, which stains nuclei black, extracellular matrix components blue, and cytoplasm and muscle fibres red. Caruncular area: sections were stained with haematoxylin and eosin. LE: luminal epithelium; GE: glandular epithelium; myo: myometrium; sc: stratum compactum stroma; ss: stratum spongiosum stroma; v: blood vessels. Scale bar of lower magnification images represents $100 \mu \mathrm{m}$ : scale bar of high magnification image of postpartum day 1 uterine glands represents $50 \mu \mathrm{m}$.

postpartum day 14 ewes, PCNA protein was very low or undetectable in all types of cell. However by postpartum day 28, PCNA protein was present in luminal epithelium in a variegated pattern and at low abundance in glandular epithelium. Regardless of postpartum day, little to no
PCNA protein was observed in the myometrium or the residual placental tissue.

Staining of in situ apoptosis was by DNA end-labelling (Fig. 4). This method recognizes DNA degradation in cells undergoing programmed cell death or apoptosis. 
Endometrium
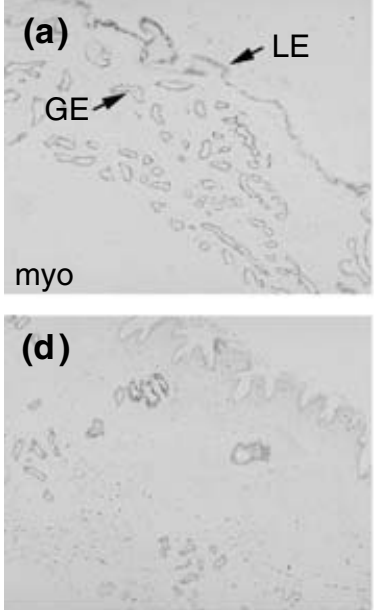

(g)
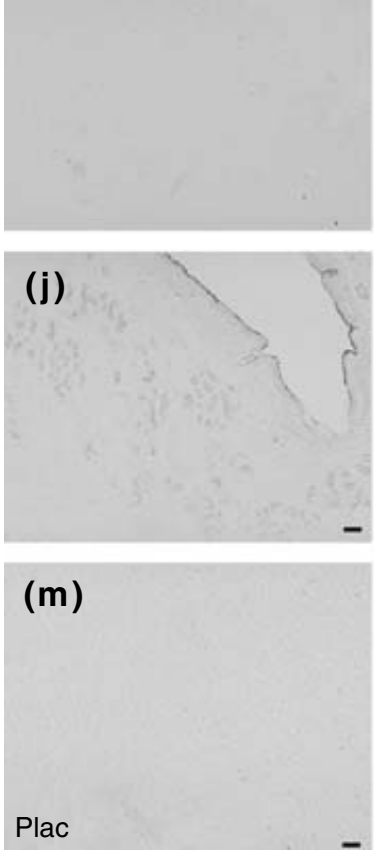

LE

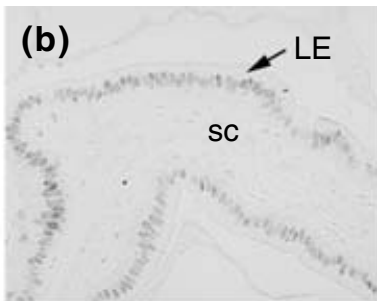

\section{(e)}

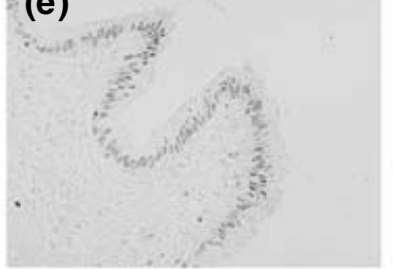

(h)
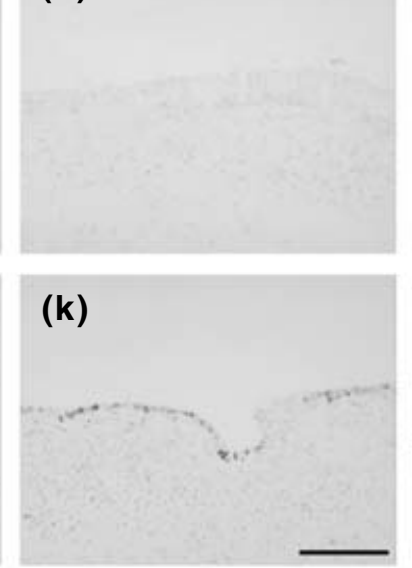

(n)

Plac
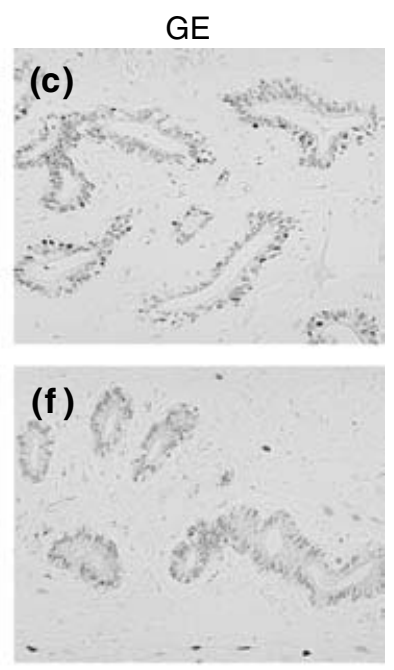

(i)

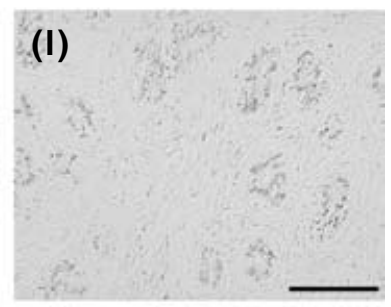

(o)

$\lg G$

Fig. 3. Immunohistochemical localization of proliferating cell nuclear antigen (PCNA) protein in the ovine uterus on $(\mathrm{a}-\mathrm{c}, \mathrm{m})$ postpartum day $1,(\mathrm{~d}-\mathrm{f}, \mathrm{n})$ postpartum day 7 , (g-i) postpartum day 14 and $(\mathrm{j}-\mathrm{l}, \mathrm{o})$ postpartum day 28 . The left column contains low power photomicrographs of the endometrium, whereas the middle column contains higher power photomicrographs of the luminal epithelia (LE) and the right column the glandular epithelia (GE) in the intercaruncular endometrium. The bottom row contains photomicrographs of the remaining placental tissue in contact with the caruncular endometrial regions on postpartum days 1 and 7, and an IgG control. myo: myometrium; Plac: placenta; sc: stratum compactum stroma. Scale bars represent $100 \mu \mathrm{m}$.

On postpartum day 1 , the large, vacuolar, nucleated cells within or between the endometrial glandular epithelia were labelled, but not the luminal epithelium, stroma or myometrium. As expected, the residual conceptus tissue that remained in the uterine lumen after parturition was also labelled.

Analyses by immunofluorescence indicated the presence of $\mathrm{CD}^{+} \mathrm{T}$ cells and BAQ44A-defined molecule 
LE

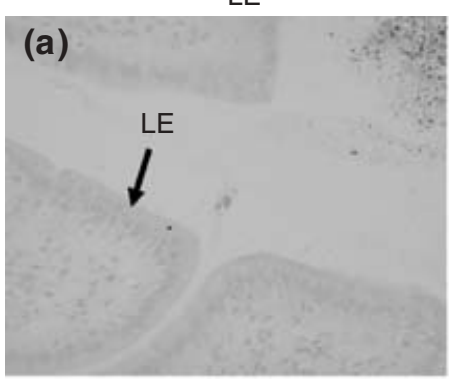

(c)
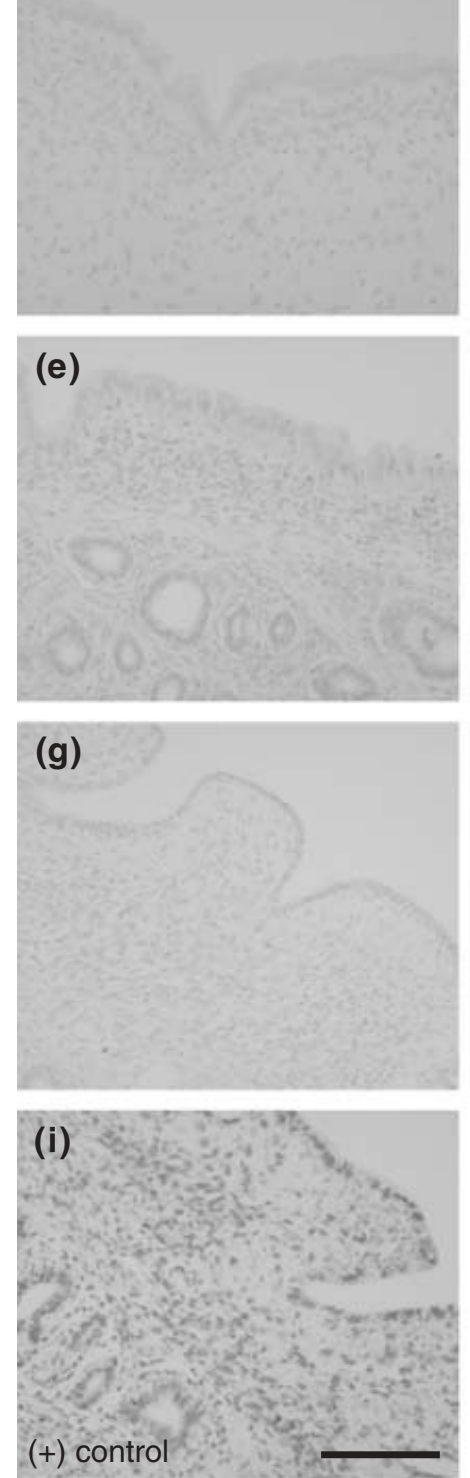

GE

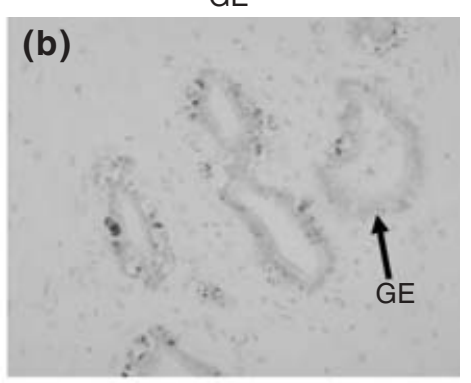

(d)
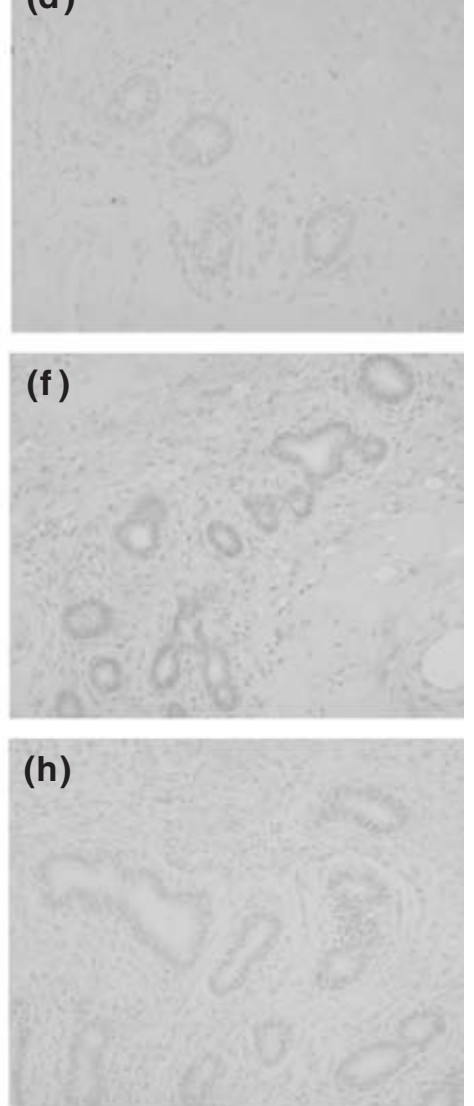

Fig. 4. In situ detection of apoptosis in the ovine uterus on $(a, b)$ postpartum day $1,(\mathrm{c}, \mathrm{d})$ postpartum day $7,(\mathrm{e}, \mathrm{f})$ postpartum day 14 and $(\mathrm{g}, \mathrm{h})$ postpartum day 28. The TACS 2TdT DAB Trevigen detection kit was used for identification of apoptotic cells. The photomicrographs in the left column are of the luminal epithelium (LE) and the right column the glandular epithelium (GE). (i) A positive DNase digested control at postpartum day 28 . Scale bar represents $100 \mu \mathrm{m}$. 

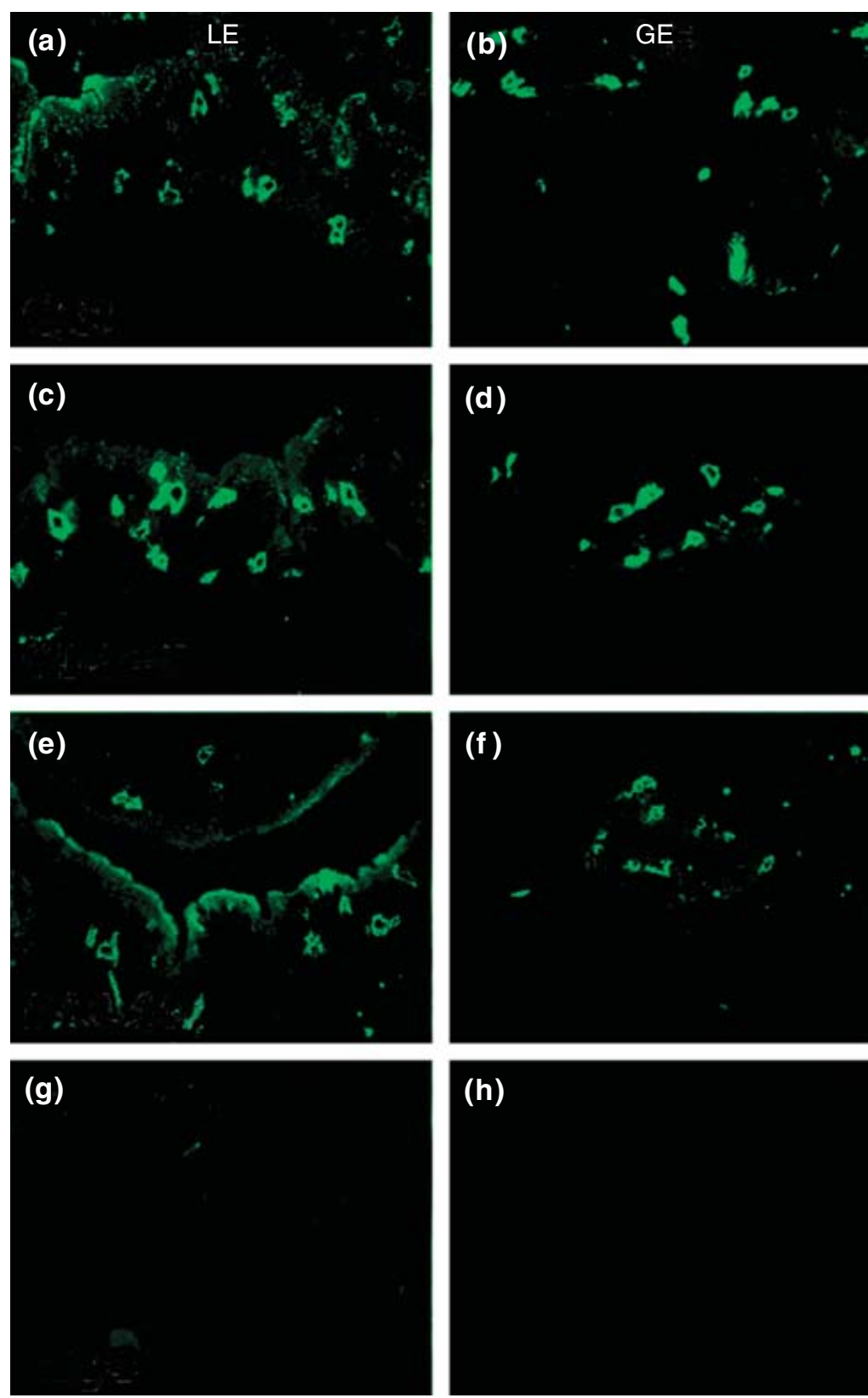

Fig. 5. Immunofluorescence detection of immune cells in the postpartum day 1 ovine uterus. (a,b) CD8 cell surface epitope expressed on T cytotoxic cells; (c,d) CD45R cell surface receptor expressed on B cells; (e,f) BAQ44a-defined molecule expressed on B cells and naive T cells; $(f, g)$ immunoreactivity was not observed when irrelevant mouse $\operatorname{lgG}(\mathrm{mlgG})$ was substituted for primary antibodies. LE: lumenal epithelium; GE: glandular epithelium. Width of field is $200 \mu \mathrm{m}$.

and $\mathrm{CD}_{45 \mathrm{R}^{+}} \mathrm{B}$ cells located within the endometrial luminal and glandular epithelium on postpartum day 1 (Fig. 5). These cells were present in all uteri on all postpartum days, but were most abundant on postpartum days 1 and 7 . These cells did not react immunologically with monoclonal antibodies specific for epitopes on $\mathrm{T}$ helper cells, monocytes, macrophages, dendritic cells, granulocytes or WC1-positive $\alpha \delta$ T cells (data not shown).
The location, number and morphology of these cells indicate that one or both of these immune cell populations represent the apoptotic cells detected by DNA endlabelling.

\section{Steroid hormone receptors in the postpartum uterus}

On postpartum day $1, E R \alpha$ protein was detected in nuclei of epithelial, stromal and myometrial cells (Fig. 6). 
ERa
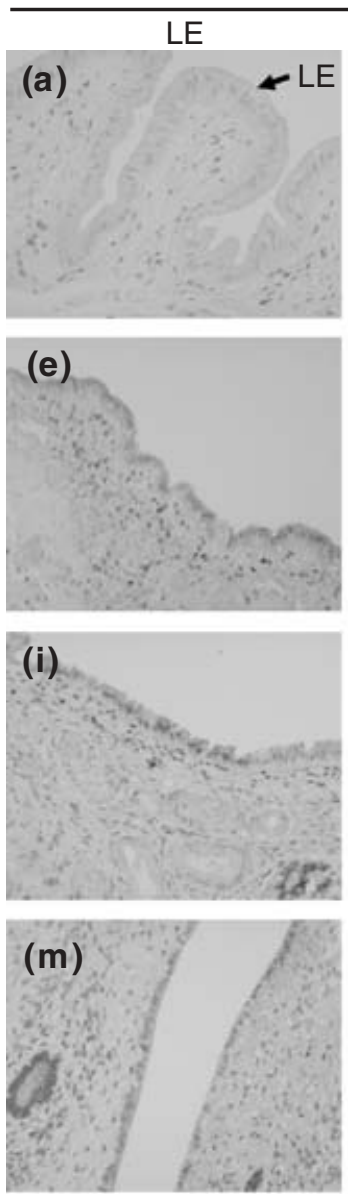

\section{Ha}
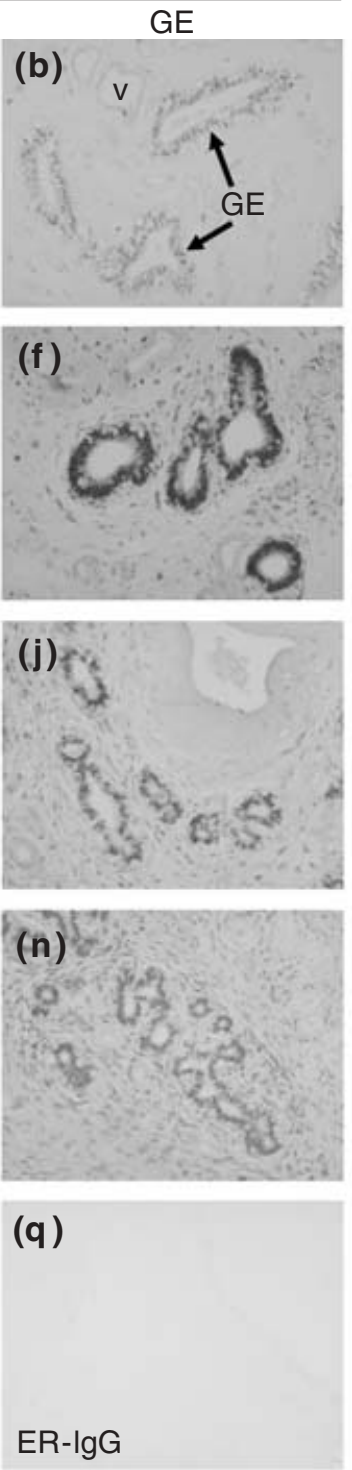

PR
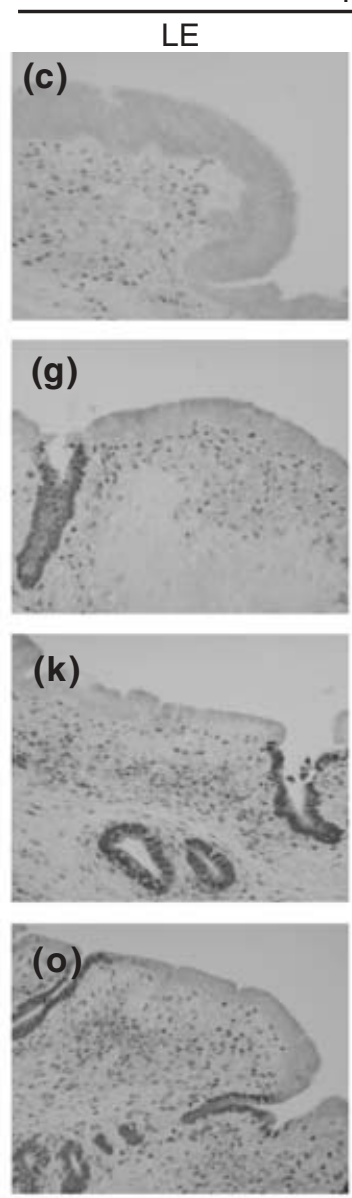

(r)

PR- $\lg G$
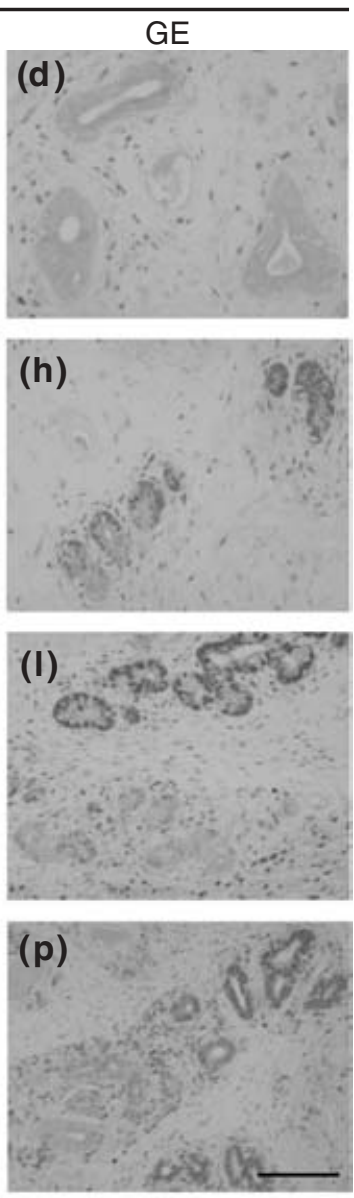

Fig. 6. Immunohistochemical localization of oestrogen receptor alpha $(E R \alpha)$ and progesterone receptor (PR) protein in the ovine uterus on $(\mathrm{a}-\mathrm{d})$ postpartum day $1,(\mathrm{e}-\mathrm{h})$ postpartum day $7,(\mathrm{i}-\mathrm{l})$ postpartum day 14 and $(\mathrm{m}-\mathrm{r})$ postpartum day 28. For each antibody used, the left column contains photomicrographs of the luminal epithelium (LE) and the right column of glandular epithelium (GE). Nuclear staining was not observed when irrelevant rat IgG was substituted for primary antibodies (IgG). v: blood vessels. Scale bar represents $100 \mu \mathrm{m}$.

The stromal cells of the stratum compactum expressed moderate to abundant amounts of $E R \alpha$ protein. On postpartum day 7 and thereafter, an increase in the overall abundance of $\mathrm{ER} \alpha$ protein was detected in the luminal epithelium, stroma and myometrium. In particular, an increase in ER $\alpha$ protein was observed in the endometrial glandular epithelium on postpartum day 7 .

Immunoreactive PR protein was not detected in the nuclei of any epithelia on postpartum day 1 (Fig. 6). However, moderate to abundant amounts of PR protein were detected in cells of the stroma and myometrium. By postpartum day 7 , abundant PR protein was detected in the superficial glandular epithelium of the stratum compactum as well as glandular epithelium present in the upper stratum spongiosum. Between postpartum days 7 and 28, PR protein was either very low or absent in luminal epithelium, but moderate or abundant in the stroma and myometrium. During this period, PR protein was observed in all superficial and middle endometrial glandular epithelium, but absent in the deeper glandular epithelium. 

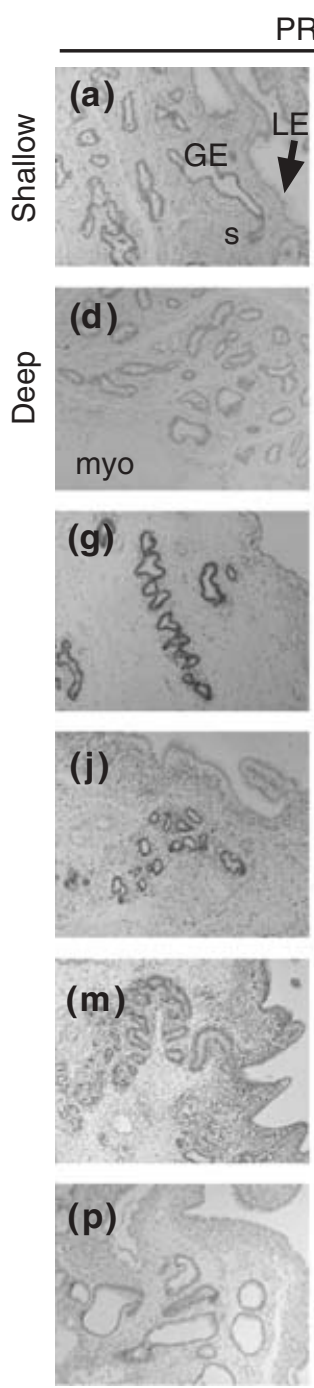

PRLR
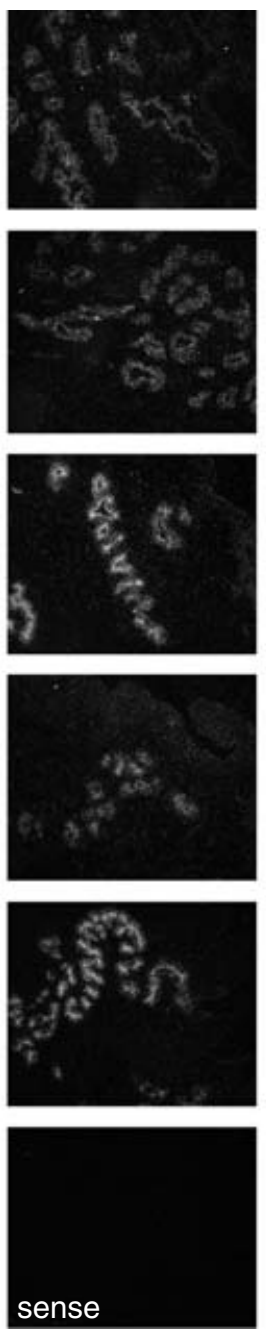

OTR

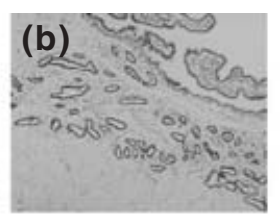

(e)
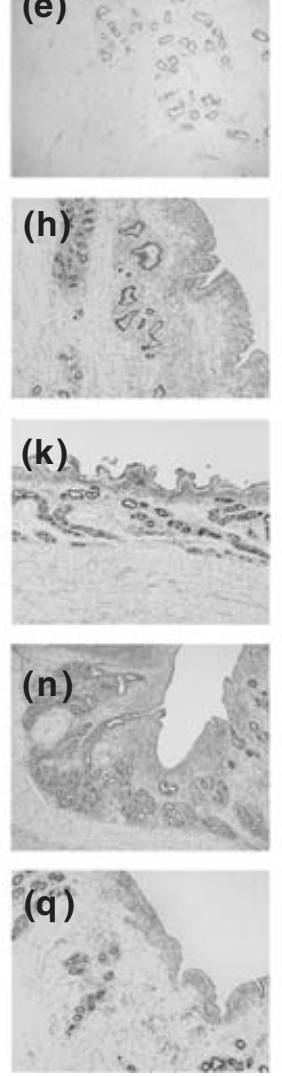
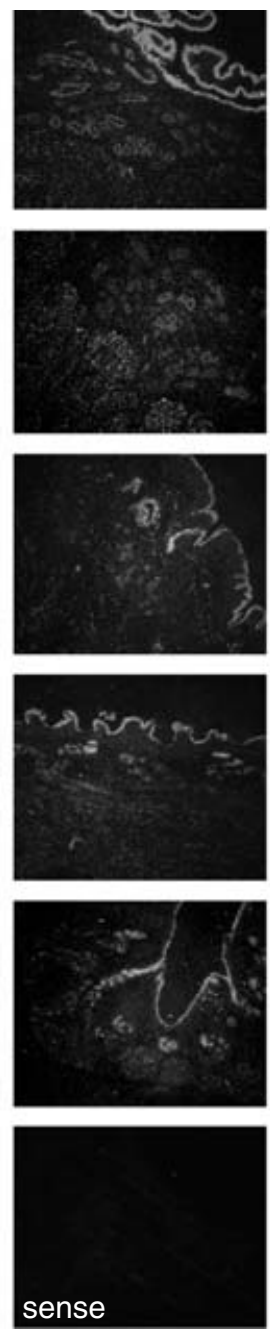
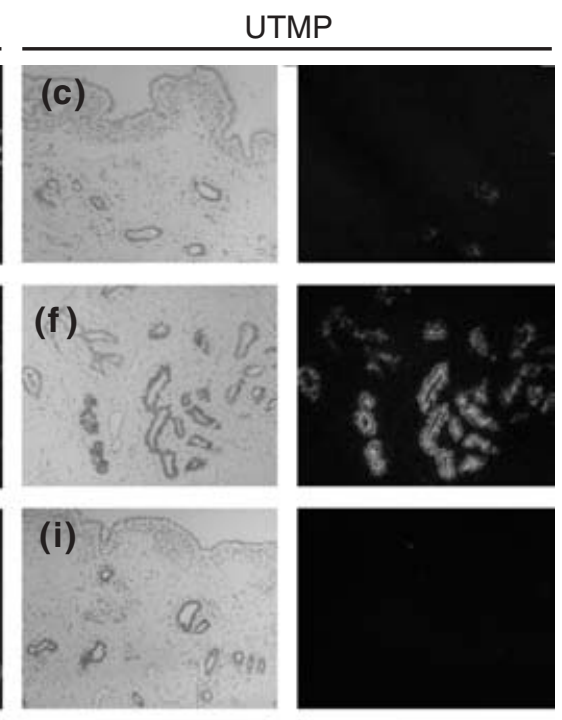

(I)
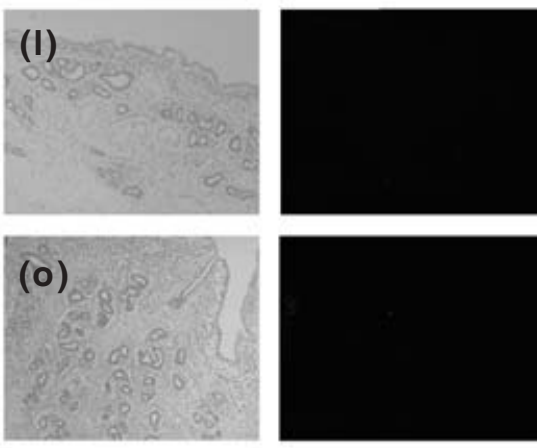

(r)
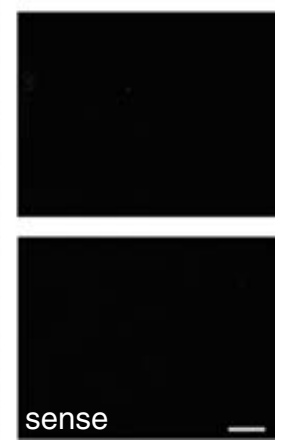

Fig. 7. In situ hybridization analysis of prolactin receptor (PRLR), oxytocin receptor (OTR) and uterine milk protein (UTMP) mRNA expression in the ovine uterus on (a-f) postpartum day 1 , (g-i) postpartum day $7,(\mathrm{j}-\mathrm{I})$ postpartum day 14 and (m-o) postpartum day 28. The top panels $(\mathrm{a}-\mathrm{c})$ are representative of the upper portion of the endometrium, whereas the bottom panels $(\mathrm{d}-\mathrm{f})$ are representative of the lower portion of the endometrium nearer the myometrium. Cross-sections of the uterine wall were hybridized with radiolabelled antisense or sense cRNA probes generated from linearized plasmid cDNA clones. Hybridized sections were digested with RNase A, and protected transcripts were visualized by liquid emulsion autoradiography. Developed slides were counterstained lightly with haematoxylin, and photomicrographs were taken under brightfield or darkfield illumination. Sense controls are shown in the bottom row. GE: glandular epithelium; LE: lumenal epithelium; s: stroma; myo: myometrium. Scale bar represents $100 \mu \mathrm{m}$.

\section{Expression of PRLR, OTR and UTMP}

Expression of PRLR mRNA was detected only in the endometrial glandular epithelium and did not appear to be affected by postpartum day (Fig. 7). In comparison with the sense control, no specific hybridization signal was detected in the residual placenta, stroma, myometrium or luminal epithelium. In the endometrium, OTR mRNA was detected in the luminal epithelium and glandular epithelium of all ewes regardless of postpartum day. Expression of the OTR mRNA was most abundant in the endometrial luminal epithelium with lower expression in the glandular epithelium and myometrium. On postpartum day 1, UTMP mRNA was detected only in the endometrial glandular epithelium of the stratum spongiosum, but not in the superficial glandular epithelium in the stratum compactum. In contrast to postpartum day 1, UTMP mRNA was not detected in the endometrial glands or any other type of cell between postpartum days 7 and 28 .

\section{Discussion}

During the postpartum period, involution of the uterus occurs in preparation for the ewe to resume oestrous cycles. Indeed, ewes exhibit decreased conception 
rates for up to 40 days postpartum (Kiracofe, 1980). As observed in previous studies (van Wyk et al., 1972a,b; O'Shea and Wright, 1984), three overlapping events occurred in the involuting ovine uterus: (1) an overall reduction in uterine size; (2) loss of conceptus tissue; and (3) tissue repair. Marked reductions in uterine wet mass (7.8-fold) and horn length (2.4-fold) were accompanied by a thinning of both the endometrium and myometrium. A noticeable decrease in the extracellular space of the endometrial stroma and an increase in ECM were detected histologically. Although changes in the ECM are involved in placentation (Ott et al., 1997), little information is available on the composition and changes in the ECM of the uterus during pregnancy or any other period of morphogenesis. Histological analyses indicated that tissue remodelling occurred in both the caruncular and intercaruncular areas of the uterine wall. This tissue remodelling did not appear to involve programmed cell death, because DNA fragmentation was observed only in the large, vacuolated cells surrounding the endometrial glands on postpartum days 1 and 7 . O'Shea and Wright (1984) suggested that these cells were dying glandular epithelium cells. However, these large cells are similar in morphology to intraepithelial lymphocytes. Immunofluorescence analyses found that these cells exhibit antigens consistent with a mixed population of lymphocytes consisting of $\mathrm{T}$ and $\mathrm{B}$ cells. Large numbers of intraepithelial immune cells in the endometrial glands have been reported during uterine development and gestation (Wimsatt, 1950; Wiley et al., 1987). Specifically, CD45R and CD8 positive immune cells are expressed in the epithelium of ewes during the oestrous cycle and early pregnancy (Segerson et al., 1991; Lee et al., 1988). Furthermore, these intraepithelial endometrial immune cells are regulated by circulating concentrations of progesterone (Gottshall and Hansen, 1992). Cell proliferation, as detected by immunoreactive PCNA distribution, was detected in the endometrial epithelia, but not in the stroma or myometrium. The simultaneous occurrence of cellular apoptosis and proliferation accompanied by remodelling of the ECM is similar to that described for mammary gland involution (Takamoto et al., 1998; Wiesen and Werb, 2000; Capuko et al., 2002). Collectively, available results indicate that the marked reductions in uterine size and horn length are due to remodelling of the ECM, loss of tissue hydration, and reduction in uterine blood flow and vascularity rather than to apoptosis.

In the caruncular areas of the uterus, loss of conceptus tissue and maternal tissue repair in the caruncle were observed between postpartum days 1 and 28. A major remodelling event was removal of the remaining placental cotyledonary tissue from the maternal caruncles between postpartum days 1 and 14 . On postpartum day 1 , the caruncles appeared distended, with a concave dark brown centre, which contained the residual portions of the placental cotyledons that form plaques. During this period, the uterine lumen contained a large amount of lochia. This thick, brownish dark fluid was generated at parturition from the leakage of blood from the extensive vascular bed of the placentome that provided haematotrophic nutrition to the fetus (van Wyk et al., 1972a). Between postpartum days 7 and 14 , the residual placental cotyledons formed plaques that were released into the uterine lumen. However, these plaques were absent on postpartum day 28, presumably due to autolysis and resorption by the uterus. In addition to changes in tissue composition and shape, a marked reduction in vascularity was also observed in both caruncular and intercaruncular areas of the uterine wall during involution. By postpartum day 28, the caruncular areas of the endometrium had remodelled from a concave to a convex shape. Between postpartum days 14 and 28, the eversion of the caruncles was accompanied by re-epitheliazation. Although this process was not complete on postpartum day 28 , it is probably a key indicator of completion of uterine involution and process in return to cyclicity. The endometrial luminal epithelium and superficial glandular epithelium are critical for cyclicity, because they produce the luteolysin, prostaglandin $\mathrm{F}_{2 \alpha}\left(\mathrm{PGF}_{2 \alpha}\right)$. Luteolytic pulses of $\mathrm{PGF}_{2 \alpha}$ are produced in response to the binding of oxytocin, produced by the posterior pituitary gland and corpus luteum, to OTR on the endometrial epithelia (see Bazer et al., 1998). Absence of either the luminal epithelium or superficial glandular epithelium renders the uterus incapable of producing luteolytic $\mathrm{PGF}_{2 \alpha}$ pulses and causes acyclicity (Gray et al., 2000a). Therefore, one aspect of involution is an increase in number of OTR and the ability to produce $\mathrm{PGF}_{2 \alpha}$ as a consequence of re-epitheliazation, or regrowth of the epithelium, of the endometrial caruncles.

In addition to the remodelling of the caruncular areas of the uterus and overall reduction in uterine size and horn length, the intercaruncular areas of the uterine wall and, in particular the endometrial glands, also exhibited retrograde changes. During pregnancy, hyperplasia and hypertrophy of the endometrial glands occurs to provide increasing amounts of histotrophic nutrition to the rapidly growing conceptus (Wimsatt, 1950; Stewart et al., 2000). Indeed, the overall secretory capacity of the uterus parallels growth and development of the fetus (Moffat et al., 1987; Stewart et al., 2000). A hormonal servomechanism involving oestrogen, progesterone, IFN- $\tau$, $\mathrm{PL}$ and placental $\mathrm{GH}$ was proposed to regulate endometrial gland morphogenesis and differentiated function (Spencer et al., 1999; Stewart et al., 2000; Noel et al., 2003). A key feature of this servomechanism is negative autoregulation of PR gene expression in the endometrial glandular epithelium by progesterone. During early pregnancy, PR gene expression becomes undetectable in the glandular epithelium after day 13 (Spencer and Bazer, 
1995) before the induction of UTMP expression between days 15 and 17 (Stewart et al., 2000). In ovariectomized ewes, treatment with progesterone downregulates PR expression, which is followed by the appearance of OPN and then UTMP expression in the endometrial glands (Moffat et al., 1987; Ing and Roberts, 1989; Spencer et al., 1999); however, addition of oestradiol to progesterone treatment prevents induction of UTMP expression by upregulating $\mathrm{PR}$, an oestrogen-responsive gene in glandular epithelium (Spencer et al., 1999).

Results from the present study lend strong support to the idea that progesterone-induced downregulation of the PR gene in the endometrial glandular epithelium is required for glandular epithelium differentiation and production of secretory proteins such as the UTMPs. Serum concentration of oestradiol were high at parturition and then peaked again on postpartum day 6 . These temporal changes in circulating oestradiol and a lack of progesterone can be correlated with the increase in ER $\alpha$ protein and OTR mRNA and induction of PR protein between postpartum days 1 and 7, which was associated with a concomitant loss of UTMP expression in the endometrial glandular epithelium. Available evidence indicates that PL acts via the PRLR to increase UTMP gene expression (Spencer et al., 1999; Herman et al., 2000). Although the cellular and molecular mechanism(s) is unknown, $\mathrm{PR}$ downregulation is required for $\mathrm{PL}$ stimulation of UTMP expression (Spencer et al., 1999). Expression of the UTMPs is a marker of differentiated glandular epithelium function. Therefore, the absence of UTMP expression and the reduction in endometrial gland width during the postpartum period indicate that the hormonal servomechanism regulating uterine gland morphogenesis during pregnancy is terminated during involution. Termination of this servomechanism appears to involve increases in ER $\alpha$ and PR expression rather than alterations in PRLR expression or cell death. Increased knowledge of the hormonal, cellular and molecular mechanisms regulating uterine involution is necessary to develop therapies to treat postpartum infertility and anoestrus in order to maximize reproductive efficiency.

The authors thank T. Welsh and T. Bryan at Texas A\&M University for assistance with radioimmunoassay; R. C. Burghardt at Texas A\&M University for assistance with immunofluorescence analyses; W. Davis at Washington State University for immune cell surface antibodies and helpful discussion; and F. W. Bazer at Texas A\&M University for helpful discussion.

\section{References}

Amoroso EC (1952) Placentation. In Marshall's Physiology of Reproduction Vol. 2 3rd Edn pp 127-311 Ed. AS Parkes. Longmans Green, London

Bazer FW, Roberts RM and Thatcher WW (1979) Actions of hormones on the uterus and effect of conceptus development Journal of Animal Science 49 Supplement 2 35-45
Bazer FW, Spencer TE and Ott TL (1998) Endocrinology of the transition from recurring estrous cycles to establishment of pregnancy in subprimate mammals. In The Endocrinology of Pregnancy pp 1-34 Ed. FW Bazer. Humana Press, Totowa, NJ

Capuko AV, Li M, Long E, Ren S, Hruska KS, Schorr K and Furth PA (2002) Concurrent pregnancy retards mammary involution: effects on apoptosis and proliferation of the mammary epithelium after forced weaning of mice Biology of Reproduction 66 1471-1476

Casida LE, Graves WE, Lauderdale JW, Riesen JW, Saiduddin S, Hauser ER and Tyler WJ (1968) Studies on the postpartum cow Research Bulletin 270 University of Wisconsin, Madison

Dunn TG, Ingalls JE, Zimmerman DR and Wiltbank JN (1969) Reproductive performance of 2-year-old Hereford and Angus heifers as influenced by pre- and post-calving energy intake Journal of Animal Science 29 719726

Gottshall SL and Hansen PJ (1992) Regulation of leucocyte subpopulations in the sheep endometrium by progesterone Immunology 76 636-641

Gray CA, Bartol FF, Taylor KM, Wiley AA, Ramsey WS, Ott TL, Bazer FW and Spencer TE (2000a) Ovine uterine gland knock-out model: effects of gland ablation on the estrous cycle Biology of Reproduction 62 448-456

Gray CA, Taylor KM, Bazer FW and Spencer TE (2000b) Mechanisms regulating norgestomet inhibition of endometrial gland morphogenesis in the neonatal ovine uterus Molecular Reproduction and Development 57 67-78

Gray CA, Bartol FF, Tarleton BJ, Wiley AA, Johnson GA, Bazer FW and Spencer TE (2001) Developmental biology of uterine glands Biology of Reproduction 65 1311-1323

Gray CA, Burghardt RC, Johnson GA, Bazer FW and Spencer TE (2002) Evidence that an absence of endometrial gland secretions in uterine gland knockout (UGKO) ewes compromises conceptus survival and elongation Reproduction 124 289-300

Herman A, Bignon C, Daniel N, Grosclaude J, Gertler A and Djiane J (2000) Functional heterodimerization of prolactin and growth hormone receptors by ovine placental lactogen Journal of Biological Chemistry 275 6295-6301

Ing NH and Roberts RM (1989) The major progesterone-modulated proteins secreted into the sheep uterus are members of the serpin superfamily of serine protease inhibitors Journal of Biological Chemistry 2643372 3379

Johnson GA, Burghardt RC, Spencer TE, Newton GR, Ott TL and Bazer FW (1999) Ovine osteopontin. II. Osteopontin and $\alpha v, \beta 3$ integrin expression in the uterus and conceptus during the peri-implantation period Biology of Reproduction 61 892-899

Johnson GA, Spencer TE, Burghardt RC, Taylor KM, Gray CA and Bazer FW (2000) Progesterone modulation of osteopontin gene expression in the ovine uterus Biology of Reproduction 62 1315-1321

Kiracofe GH (1980) Uterine involution: its role in regulating postpartum intervals Journal of Animal Science 51 Supplement 2 16-28

Lee CS, Gogolin-Ewens K and Brandon MR (1988) Identification of a unique lymphocyte subpopulation in the sheep uterus Immunology 63 157-164

Marion GB and Gier HT (1968) Factors affecting bovine ovarian activity after parturition Journal of Animal Science 27 1621-1626

Moffatt J, Bazer FW, Hansen PJ, Chun PW and Roberts RM (1987) Purification, secretion and immunocytochemical localization of the uterine milk proteins, major progesterone-induced proteins in uterine secretions of the sheep Biology of Reproduction 36 419-430

Noel S, Herman A, Johnson GA, Gray CA, Stewart MD, Bazer FW, Gertler A and Spencer TE Ovine placental lactogen specifically binds endometrial glands of the ovine uterus Biology of Reproduction $\mathbf{6 8}$ (in press)

O'Shea JD and Wright PJ (1984) Involution and regeneration of the endometrium following parturition in the ewe Cell and Tissue Research 236 477-485

Ott TL, Wiley AA and Bartol FF (1997) Effects of stage of gestation and uterine ligation on ovine placentome development and glycosaminoglycans Journal of Animal Science 75 1053-1062

Rasbeck NO (1950) Den normale involutio uteri hos koen Nordic Veterinary Medicine 2655 
Riesen JW (1968) The effects of suckling on reproductive function in postpartum dairy cows - pituitary prolactin, corpora lutea, and uterine histology PhD Thesis, University of Wisconsin, Madison

Riley PR, Abayasekara DR, Stewart HJ and Flint AP (1996) Functional characterisation of an ovine endometrial oxytocin receptor cDNA transiently expressed in Cos-7 cells Journal of Endocrinology 149389 396

Scott P, Kessler MA and Schuler LA (1992) Molecular cloning of the bovine prolactin receptor and distribution of prolactin and growth hormone receptor transcripts in fetal and utero-placental tissues Molecular and Cellular Endocrinology 89 47-58

Segerson EC, Matterson PM and Gunsett FC (1991) Endometrial T-lymphocyte subset infiltration during the ovine estrous cycle and early pregnancy Journal of Reproductive Immunology 20 221-236

Spencer TE and Bazer FW (1995) Temporal and spatial regulation of uterine receptors for estrogen and progesterone during the estrous cycle and early pregnancy in ewes Biology of Reproduction 53 1527-1544

Spencer TE and Bazer FW (2002) Biology of progesterone action during pregnancy recognition and maintenance of pregnancy Frontiers in Bioscience 7 1879-1898

Spencer TE, Mirando MA, Mayes JS, Watson GH, Ott TL and Bazer FW (1996) Effects of interferon-tau and progesterone on oestrogenstimulated expression of receptors for oestrogen, progesterone and oxytocin in the endometrium of ovariectomized ewes Reproduction, Fertility and Development 8 843-853

Spencer TE, Gray A, Johnson GA, Taylor KM, Gertler A, Gootwine E, Ott TL and Bazer FW (1999) Effects of recombinant ovine interferon tau, placental lactogen, and growth hormone on the ovine uterus Biology of Reproduction 61 1409-1418

Statistical Analysis System Institute (2000) SAS Users Guide: Statistics Version 9 Statistical Analysis System Institute, Inc., Cary, NC

Stewart MD, Johnson GA, Gray CA, Burghardt RC, Schuler LA, Joyce MM, Bazer FW and Spencer TE (2000) Prolactin receptor and uterine milk protein expression in the ovine endometrium during the estrous cycle and pregnancy Biology of Reproduction 62 1779-1789

Takamoto N, Leppert PC and Yu SY (1998) Cell death and proliferation and its relation to collagen degradation in uterine involution of rat Connective Tissue Research 37 163-175

van Wyk LC, van Niekerk CH and Belonje PC (1972a) Involution of the post partum uterus of the ewe Journal of the South African Veterinary Association 43 19-26

van Wyk LC, van Niekerk CH and Bolonje PC (1972b) Further observations on the involution of the post partum uterus of the ewe Journal of the South African Veterinary Association 43 29-33

Waseem NH and Lane DP (1990) Monoclonal antibody analysis of the proliferating cell nuclear antigen (PCNA). Structural conservation and the detection of a nucleolar form Journal of Cell Science 96 $121-129$

Wiesen J and Werb Z (2000) Proteinases, cell cycle regulation and apoptosis during mammary gland involution Molecular Reproduction and Development 56 534-540

Wiley AA, Bartol FF and Barron DH (1987) Histogenesis of the ovine uterus Journal of Animal Science 64 1262-1269

Wiltbank JN and Cook AC (1958) The comparative reproductive performance of nursed milked cows Journal of Animal Science 17 640-648

Wiltbank JN, Rowden NW, Ingalls JE, Gregory KE and Koch RM (1962) Effects of energy level on reproductive phenomena in mature Hereford cows Journal of Animal Science 21 219-225

Wimsatt WA (1950) New histological observations on the placenta of the sheep American Journal of Anatomy 87 391-436

Received 7 August 2002.

First decision 19 September 2002.

Revised manuscript received 17 October 2002.

Accepted 18 October 2002. 